\title{
Sankcje Unii Europejskiej wobec Rosji: proces decyzyjny, trwałość i rola państw członkowskich
}

\section{Wprowadzenie}

Od marca 2014 r. Unia Europejska stopniowo wprowadzała środki ograniczające wobec Rosji. Środki zostały przyjęte w odpowiedzi na nielegalną aneksję Krymu i celową destabilizację Ukrainy. Unia Europejska w szczególności nałożyła następujące środki ograniczające relacje z Rosją: środki dyplomatyczne; indywidualne środki ograniczające (zamrożenie aktywów i ograniczenia w podróżowaniu); ograniczenia w stosunkach gospodarczych z Krymem i Sewastopolem; sankcje ekonomiczne; oraz ograniczenia w zakresie współpracy gospodarczej.

Powyższe środki ograniczające określane są w decyzjach Rady w sprawie wspólnej polityki zagranicznej i bezpieczeństwa (WPZiB - Common Foreign and Security Policy (CFSP) Council), które podjęte zostają na podstawie wniosku złożonego przez wysokiego przedstawiciela Unii do spraw zagranicznych i polityki bezpieczeństwa (the High Representative of the Union for Foreign Affairs and Security Policy). Niemniej jednak zanim decyzja zostanie podjęta, proponowane środki są analizowane i omawiane przez odpowiednie organy przygotowawcze Rady. Jednym z takich organów jest grupa robocza rady odpowiedzialna za region geograficzny, do którego należy docelowe państwo, grupa robocza ds. Europy Wschodniej i Azji Środkowej (COEST). Innymi organem jest grupa doradcza ds. współpracy z zagranicą (RELEX), oraz w razie potrzeby Komitet polityczny i bezpieczeństwa (PSC), jak i Komitet stałych przedstawicieli (COREPER II)

Niniejszy artykuł analizuje proces decyzyjny w UE w odniesieniu do nakładania i rozszerzania sankcji wobec Rosji. W szczególności celem artykułu jest analiza procesu decyzyjnego dotyczącego nakładania oraz przedłużania sankcji UE wobec Rosji oraz ocena przyczyny trwałości decyzji oraz porozumienia między państwami członkowskimi UE. Artykuł odpowiada na pytanie jak możemy zrozumieć jednomyślność pomiędzy państwami, chociaż proces negocjacji jest złożony i zależy od wzajemnych oddziaływań różnych czynników (ekonomicznych, historycznych i kulturowych).

Badania oparte są na materiałach zebranych podczas wizyty w instytucjach Unii Europejskiej, a w szczególności na wywiadach przeprowadzonych przez autora z przedstawicielami Stałych Przedstawicielstw państw członkowskich przy Unii Europejskiej w Brukseli, które zostały przeprowadzone w grudniu 2017 roku. Przedstawiciele pytani byli o stanowisko w sprawie sankcji nałożonych na Rosję w 2014 roku oraz przedłużenia sankcji, opinii na temat odmiennego stanowiska innych państw członkowskich, proces decyzyjny i dynamikę w ramach grup robo- 
czych Rady, a w szczególności COEST (Grupa Robocza ds. Europy Wschodniej i Azji Środkowej) dla Ukrainy lub Białorusi, Rosji.

\section{Przyczyny nakladania sankcji i ich wplyw}

Kiedy wysiłki dyplomatyczne zawodzą, organizacje międzynarodowe wywierają wpływ na państwa, stosując różnego rodzaju narzędzia ograniczające w celu spowodowania faktycznych kosztów i strat tak, aby wymusić odpowiednie zachowanie na kraju odbiorcy. Presja może przybrać formę nacisku wojskowego, kulturowego, politycznego, ekonomicznego lub finansowego, w zależności od dostępnych narzędzi oraz celów sankcji (Tostensen, Bull, 2002). Celem sankcji jest sygnalizowanie, że pewne postawy polityczne danego państwa są niedopuszczalne i dlatego powinno być karane.

Organizacja Narodów Zjednoczonych, Stany Zjednoczone i Unia Europejska są głównymi nadawcami sankcji. Sankcje dokonywane przez nie były często stosowane po II wojnie światowej i znacznie wzrosły w erze postzimnowojennej (Hufbauer et al., 2007). W latach 90. miało miejsce ponad pięćdziesiąt nowych epizodów sankcji, w tym 12 przypadków sankcji nałożonych przez Radę Bezpieczeństwa ONZ, a reszta to przede wszystkim Stany Zjednoczone i Unia Europejska (Askari, Forrer, Teegen, Yang, 2003; Cortright, Lopez, 2000). Unia Europejska, Stany Zjednoczone i Organizacja Narodów Zjednoczonych coraz częściej stosowały sankcje w celu wzmocnienia demokracji i praw człowieka na całym świecie.

Większość krajów, na które ONZ, Stany Zjednoczone i UE nakładają sankcje ekonomiczne, to autorytarne reżimy (Escribà-Folch, Wright, 2010; Escribà-Folch, 2012). W szczególności w niektórych przypadkach stosowano sankcje, aby zmusić kraj docelowy do wycofania swoich wojsk z terenu innego kraju, do zaprzestania ekspansywnej polityki zagranicznej i działań związanych z wojną i bezpieczeństwem narodowym. Ponadto, sankcje były stosowane za naruszenie norm demokratycznych i praw człowieka, w celu powstrzymania prób destabilizacji rządów innych państw, powstrzymania rozprzestrzeniania broni jądrowej i zwalczania międzynarodowego terroryzmu ${ }^{1}$. Oprócz osłabiania państw docelowych i wywierania nacisku, celem sankcji jest polityczne wyizolowanie ze społeczności międzynarodowej (Drury, Peterson, 2011; Galtung, 1967). Przyjęta przez naukowców definicja „sukcesu sankcji” zakłada, że sankcje będą wtedy skuteczne kiedy rząd państwa, na które sankcje zostały nałożone, zmieni swoją politykę i ulegnie naciskowi.

Niemniej jednak pomimo istotnych powodów dla których sankcje były i są nakładane, niektórzy uczeni badający skuteczność sankcji dochodzą do wniosku, że jest to narzędzie przynoszące efekt przeciwny do zamierzonego (Stępień, Pospieszna, Skrzypczyńka, 2016; Escribà-Folch, Wright, 2010; Peksen, 2009; Peksen, Drury, 2010). Wiele przykładów historycznych pokazuje, że sankcje ekonomiczne czasami się udają, ale często nie wywołują pożądanej zmiany polityki (Allen, 2005). Wnioski takie rodzą pytanie, dlaczego inne państwa, jak i organizacje, takie jak Unia Europejska, często wprowadzały sankcje i czy ta forma nacisku jest skuteczna, a jeśli tak,

${ }^{1}$ Historyczny przegląd sankcji gospodarczych po II wojnie światowej w Hufbauer, Schott i Elliott (1990). 
w jakich okolicznościach liderzy są gotowi do kompromisu pod presją wywartą przez sankcje, a w jakich nie są skłonni do ustępstw (Art, Cronin, 2003; Lindsay, 1986; Elliott, Uimonen, 1993; Pape, 1998).

Nadal mamy niewielką wiedzę na temat początku, skutków i skuteczności sankcji, a szczególnie nie znamy dokładnie warunków, w jakich Unia Europejska, która mimo wszystko jest organizacją wielostronną, używa ich i z jakim powodzeniem. Unia Europejska uznaje sankcje za ,podstawowe narzędzie polityki zagranicznej UE, które wykorzystuje do realizacji celów zgodnie z zasadami wspólnej polityki zagranicznej i bezpieczeństwa". Praktycznie może to przybrać formę embargo na broń, zakaz w sprawie świadczenia niektórych usług, zamrożenia funduszy i zasobów gospodarczych, ograniczenia w dostępie do $\mathrm{UE}^{2}$. Badania realizowane w ramach tego projektu przyczynią się przede wszystkim do lepszego rozumienia przyczyn i skuteczności sankcji nakładanych przez Unię Europejską. Istnieje obecnie 85 aktywnych sankcji, które Unia nałożyła i w większości są one powiązane z polityką wewnętrzną. Są to głównie kraje afrykańskie (np. Burundi, Kongo, Gwinea Równikowa, Gwinea, Liberia, Sudan, Togo, Zimbabwe itd.) oraz kraje Europy Wschodniej i Bałkanów (Białoruś, Bośnia i Hercegowina, Macedonia, Rosja, Serbia oraz Czarnogóra, Ukraina i Uzbekistan) (Pospieszna, Weber, 2017).

Należy jednak zaznaczyć że istnieje niewiele badań dotyczących sankcji UE i bardziej kompleksowej oceny procesu decyzyjnego (Eriksson, 2011). UE opierała się na sankcjach od czasu zakończenia zimnej wojny. Niemniej jednak badania dotyczące sankcji UE są bardzo rzadkie. W rzeczywistości niewiele wiemy o początkach sankcji, ich wpływie i skuteczności. Tylko Eriksson (2011), Giumelli (2011) i Portela (2012) podjęli wysiłek zbadania uwarunkowań sukcesu i porażki sankcji UE. Co więcej, polityka sankcjonowania tej ponadnarodowej organizacji spotyka się z ostrą krytyką. Zastrzeżenia te dotyczą zarzutów, że unijne sankcje nakładane na niewłaściwe państwa oraz że skutki są albo znikome, albo wręcz przeciwne do zamierzonych.

Z pewnością badając sankcje UE należy wziąć pod uwagę fakt, że sankcje UE różnią się od tych nakładanych przez USA lub ONZ. Różnice wynikają ze strategicznych motywacji, ponieważ każde stanowisko UE które jest podstawą do nakładania środków ograniczających wymaga jednomyślności ze strony wszystkich państw członkowskich UE w Radzie - co zmniejsza ryzyko, że sankcje są nakładane z innych powodów, jak w przypadku USA (Schneider, Weber, 2017). Ponadto, ze względu na swoją siłę gospodarczą oraz otwarcie na nowe kraje członkowskie, UE może zaoferować namacalne zachęty w zamian za spełnienie żądań, które wykraczają poza wsparcie finansowe bądź zacieśnianie stosunków handlowych. Portela (2012) pokazuje, że liczba podmiotów biorących udział w procesie nakładania sankcji przez UE, oraz cel działań, mają istotny wpływ na skuteczność sankcji nakładanych przez UE. Porównując sankcje UE i ONZ, Giumelli (2011) odnosi się do potrzeby bardziej szczegółowej analizy sankcji na poziomie mikro celu lepszego zrozumienia poszczególnych przypadków sankcji nakładanych przez UE.

${ }^{2} \mathrm{http}$ ://eeas.europa.eu/cfsp/sanctions/index_en.htm. Ta strona internetowa zawiera również listę aktualnie nałożonych przez organizację sankcji (http://eeas.europa.eu/cfsp/sanctions/docs/measures_en.pdf). 


\section{Sankcje Unii Europejskiej wobec Rosji}

Sankcje unijne wobec Rosji zapoczątkowane były zastosowaniem narzędzi dyplomatycznych, które polegały na tym że w 2014 r. Szczyt UE-Rosja został odwołany, a państwa członkowskie UE zawiesiły regularne spotkania dwustronne. Ponadto, rozmowy bilateralne $\mathrm{z}$ Rosją w sprawach wizowych, a także w sprawie nowej umowy między UE a Rosją zostały zawieszone. Ponadto, zastosowane zostały indywidualne sankcje, ograniczenia dotyczące zamrożenia aktywów i zakazu podróżowania osób odpowiedzialnych za działania podważające lub zagrażające integralności terytorialnej, suwerenności i niezależności Ukrainy³. W marcu 2014 r. Rada postanowiła zamrozić aktywa osób odpowiedzialnych za sprzeniewierzenie ukraińskich funduszy państwowych oraz wprowadzić ograniczenia w stosunkach gospodarczych z Krymem i Sewastopolem. Rada przyjęła środki ograniczające dotyczące zakazu importu towarów z Krymu i Sewastopola, ograniczenia handlu i inwestycji związanych z niektórymi sektorami gospodarki i projektami infrastrukturalnymi, zakaz świadczenia usług turystycznych na Krymie lub w Sewastopolu, zakaz wywozu niektórych towarów i technologii.

W następnej kolejności w lipcu i wrześniu 2014 r., w ramach trzeciej fali sankcji, UE nałożyła sankcje gospodarcze na wymianę z Rosją w określonych sektorach gospodarki. Sankcje ekonomiczne przedłużane są co 6 miesięcy każdorazowo po dokonaniu oceny realizacji umów z Mińska. Restrykcyjne środki dotyczą ograniczonego dostępu do podstawowych i wtórnych rynków kapitałowych UE dla niektórych rosyjskich banków i spółek; zakaz wywozu i przywozu na handel bronią, wywozu towarów podwójnego zastosowania do celów wojskowych; ograniczony dostęp do niektórych wrażliwych technologii i usług, które można wykorzystać do produkcji i eksploracji ropy naftowej. W lipcu 2014 r. przywódcy UE również wprowadzili ograniczenia w zakresie współpracy gospodarczej.

\section{Stanowisko państw członkowskich $w$ ramach COEST przed nałożeniem sankcji}

W 2012 roku relacje pomiędzy UE a Rosją postrzegane były przez przedstawicieli Stałych Przedstawicielstw być może nie jako te w stanie rozkwitu, ale przynajmniej w stanie „normalnego" funkcjonowania. Odbywały się wtedy zebrania i posiedzenia rad sektorowych: do spraw środowiskowych, energetyki i tym podobne, a agendy były wtedy przygotowywane przez COEST, która jest grupą roboczą wypracowującą stanowiska państw członkowskich, czyli stanowisko Unii na podstawie stanowisk poszczególnych państw w zakresie działań w obrębie szeroko rozumianego wschodu: Rosja, Ukraina, Białoruś, Kaukaz, Azja Centralna, ale również Arktyka i Grenlandia. Już wtedy istniało wiele problemów w relacjach unijno-rosyjskich, które w ramach grupy roboczej COEST oraz wyżej na komitetach musiały być rozstrzygane, ale jednak były

3 Środki zostały wprowadzone w marcu 2014 i są regularnie przedłużane. Wykaz osób i podmiotów objętych unijnymi środkami ograniczającymi w odniesieniu do integralności terytorialnej Ukrainy: http://www.consilium.europa.eu/en/press/press-releases/2017/03/13/eu-sanctions-ukraineintegrity/. 
to regularne formaty spotkań. Natomiast potem wraz z pierwszą, potem drugą i trzecią falą sankcji wszystkie zostały zawieszone.

Przed nałożeniem sankcji w ramach grupy COEST można było zaobserwować wyraźną dynamikę i bardzo wyraźny podział między grupami państw członkowskich opowiadających się za bardziej asertywnym, bardziej zdecydowanym stanowiskiem wobec Rosji, jak i tych, które z powodów historycznych czy ekonomicznych, biznesowych są tradycyjnie i historycznie dużo bardziej otwarte na współpracę z Rosją. Ten podział w COEST był zakorzeniony, tradycyjnie ukształtowany. W czasach spokojnych relacji z reguły ten podział jest widoczny i mocno wpływa na pracę grupy roboczej. Wpływa w ten sposób, że grupa państw bałtyckich do której należy Szwecja, Wielka Brytania, Polska, Dania, jak również Rumunia, prezentują stanowisko, które zawsze sprowadza się do tego, żeby wzmacniać sankcje wobec Rosji, żeby sankcje były jak najdalej idące i jak najbardziej skuteczne, oraz aby je przedłużać, gdy już są wprowadzone.

Natomiast druga grupa państw południa Europy - Hiszpania, Włochy, Portugalia, Grecja, Cypr - jest tradycyjnie, historycznie skłonna do angażowania Rosji na zasadzie „Realpolitik”. Państwa te historycznie nie miały problemów z Rosją z powodu oddalenia geograficznego, a wręcz Rosja dopomogła im w odzyskaniu niepodległości jak w przypadku Grecji, a w przypadku Cypru wzmacniała ekonomicznie (na Cyprze istnieje spora mniejszość rosyjska). Państwa te mają tendencję do nie tyle ulegania wpływom rosyjskim, ale do bardziej pobłażliwego w stosunku do Rosji formowania swojego stanowiska politycznego. Jest to przeciwność grupy antyrosyjskiej tzw. państw ,like-minded”, opisanej powyżej.

Francja i Niemcy przed kryzysem ukraińskim bardziej skłaniały się do stanowiska państw śródziemnomorskich, do biznesowego, dość pobłażliwego i angażującego stanowiska wobec Rosji. Polega ono na niezrywaniu kontaktów, staraniu się rozmawiać nawet w przypadku, gdy wyraźnie widać, że to Rosja tworzy problemy w relacjach dwustronnych między Moskwą a Unią. Zarówno Francja, jak i Niemcy cierpiały z powodu różnych nieprzychylnych kroków gospodarczych typu embargo, nieprzestrzeganie zasad WTO, politycznego wykorzystywania środków o charakterze kontroli żywności. Mimo tego starały się te kontakty z Rosją utrzymywać i absolutnie nie przychodziło im na myśl że w 2013 roku może nadejść taki moment, że relacje Unii z Rosją radyklanie zmienią się i że cała infrastruktura kontaktów wypracowana od trudniej połowy lat 90-tych (szczyty UE-Rosja, rady sektorowe, tzw. stała rada partnerstwa) ulegnie zburzeniu.

Choć sytuacja była napięta i szczyty Unia Europejska-Rosja nie przynosiły rezultatów, relacje były utrzymywane i taka była sytuacja wyjściowa w 2012 roku przed wybuchem kryzysu ukraińskiego. Kiedy kryzys ukraiński skutkował aneksją Krymu ten decydujący moment zmienił radykalnie podejście do Rosji. Kryzys ten unieważnił tradycyjne stanowiska polityczne opisane powyżej. „Wytworzył się w Radzie, nie tylko w COEST, klimat polityczno-dyplomatyczny, że nawet państwa 'sympatyzujące’ z Rosją; nawet zwolennicy podejścia biznesowo-real-politycznego (Grecy, Włosi itd.) nie mieli w kieszeni żadnych argumentów, które mogliby wykorzystać, żeby powstrzymać falę sankcji, która nastała ze strony Unii"4.

${ }^{4}$ Wywiad z przedstawicielem Stałego Przedstawicielstwa Republiki Estonii przy Unii Europejskiej, 5 grudnia 2017, Bruksela, Belgia. 
Pomimo, że decyzje w sprawie sankcji przypadały na czas prezydencji greckiej i włoskiej, żadne z tych państw tradycyjnie ,prorosyjskich” nie podjęło żadnych kroków, żeby zatrzymać tę asertywną w tym momencie politykę Unii związaną z nałożeniem na Rosję sankcji. W przekonaniu osób, z którymi przeprowadzone zostały wywiady, Unia jak na swoją zwyczajową powolność, słabość szybkiego reagowania i wymiar biurokratycznego molocha, potrafiła w tym decydującym momencie pokazać jedność i taką siłę, na jaką ją stać. Unia potrafiła przezwyciężyć swój wewnętrzny podział na zwolenników ostrej linii wobec Rosji i zwolenników pobłażliwości, a w konsekwencji przyjęła pierwszą falę sankcji.

\section{Sankcje jako prawdziwy konsensus w UE?}

Istnieje przekonanie, że sankcje unijne nałożone na Rosję pokazały prawdziwy konsensus w UE na ten określony moment polityczno-dyplomatyczny. Rosja wytrąciła wszystkie argumenty tym, którzy mieliby ochotę jej bronić. Pierwsza fala objęła zawieszenie kontaktów i zawieszenie formatów (szczytów itd.). Potem niemal od razu była druga fala sankcji indywidualnych wobec osób i podmiotów gospodarczych, a trzecia fala na początku lata to były sankcje sektorowe, dużo poważniejsze i bardziej przemyślane. To był konsensus na określony moment wywołany działaniami Rosji, których nie dało się usprawiedliwić i które były jaskrawo sprzeczne z prawem międzynarodowym, w związku z tym nikt nie mógł zaprotestować przeciwko kontr-działaniom ze strony unijnej. Jednocześnie przedstawiciele COEST podkreślają, że istnieje obawa że konsensus ten nie jest konsensusem, który się utrzyma na zawsze, jak jeden z rozmówców to ujął: „Taki konsensus w UE można uzyskać tylko w chwili bitewnej, tylko w chwili wielkiego napięcia"s.

Można powiedzieć, że Francja i Niemcy to są te państwa, które utrzymują konsensus i ideologiczne, pryncypialne nastawienie. Stanowisko niemiecko-francuskie, przed kryzysem ukraińskim zbliżone do podejścia transakcyjnego państw południa Europy, niemniej jednak zmieniło się, w sytuacji konfliktu kiedy państwa te wystąpiły jako bardzo aktywni brokerzy w sprawach uregulowania konfliktu na wschodzie Ukrainy. Póki co, państwa te są związane swoim stanowiskiem i nie mogą prowadzić polityki wobec Rosji taką, jaką by chciały. Od tego momentu stanowisko francusko-niemieckie wobec Rosji stało się dużo bardziej pryncypialne.

Istniały próby osłabienia konsensusu poprzez kontra sankcje nałożone przez Rosję na Unię Europejską, w momencie kiedy zachodni świat nałożył sankcję na Rosję. Kontrsankcje były próbą dzielenia Unii Europejskiej, a w szczególności nałożone wybiórczo embarga żywnościowe, po to, aby pogłębiać wewnętrzne podziały w UE. Oczywiście dochodzą do tego różne inne działania Rosji nastawione na dzielenie opinii publicznej w krajach zachodnich. Jest to jeden z elementów tworzenia podziałów wewnątrz Unii, poszukiwania sojuszników i kreowania korzystnego dla siebie środowiska międzynarodowego.

W ocenie urzędników UE działania Rosji podważające zgodność i trwałość postawy UE w sprawie sankcji niczego nie spowodowały do tej pory. W ramach spotkań

${ }_{5}^{5}$ Wywiad z przedstawicielem Stałego Przedstawicielstwa Rzeczpospolitej Polskiej przy Unii Europejskiej, 5 grudnia 2017, Bruksela, Belgia. 
COEST jest obecnie mało dyskusji o Rosji, ale widać, że powoli (pomimo braku zmiany okoliczności) wraca nieśmiało tendencja do „,business as usual” ze strony niektórych państw tradycyjnie bardziej wobec Rosji pobłażliwych. Oznacza to, że udało się osiągnąć konsensus i zmienić postawę państw bardziej przychylnych Rosji, w pewnym momencie historycznym, na stanowisko bardziej asertywne wobec Rosji, ale istnieje ryzyko, że po kilku latach, gdy emocje opadną, wrócą pewne klasyczne stosunki, tak jak to miało miejsce przed sankcjami w 2012 roku.

\section{Proces decyzyjny zwiazany z nakładaniem i przedlużaniem sankcji}

COEST decydował tylko na samym początku, gdy kontakty z Rosją były zawieszane podczas pierwszej fali. We wszelkich krokach sankcyjnych z zakresu trzeciej fali sektorowej COEST nie uczestniczył z natury, a wprowadzały je COREPER z RELEX. To były sankcje obejmujące specyficzne dziedziny, co do których COEST nie ma kompetencji, ponieważ jest to grupa polityczna. COREPER zlecał RELEX przygotowanie poszczególnych aktów prawnych. Sankcje indywidualne nakładał również COREPER.

W okresie tworzenia nowego status quo 2013 i 2014 roku, czyli polityki sankcyjnej bardzo aktywnej, kluczową rolę odgrywał COREPER. Odnośnie dyskusji na temat tego, jakie sektory obejmować sankcjami i w sprawach sankcji indywidualnych odbywały się na szczeblu COREPER. W związku z tym, że co miesiąc odbywały się posiedzenia rady w sprawie Ukrainy, COEST również pełnił bardzo aktywną rolę, spotykając się na codziennych posiedzeniach, z których tworzył konkluzje i przekazywał Radzie. To głównie COEST dyskutował na temat sankcji nałożonych na Ukrainę, na Janukowycza i współpracowników, robi to po części cały czas, choć ostatnio coraz więcej zajmuje się tym RELEX. RELEX ma znaczenie pod względem przygotowania aktów prawnych, analizy i przede wszystkim obróbki spraw, które wnoszą osoby na listach sankcyjnych do sądu unijnego, do ETS.

Rola COEST była stosunkowo ograniczana $\mathrm{i}$ w obecnej sytuacji COEST nie ma nic do powiedzenia w kwestii sankcji sektorowych. Co do indywidualnych sankcji, to COEST odpowiedzialny jest za sprawdzanie list osób i wydaje opinię odnośnie przedłużeń, czyli rola COEST sprowadza się do technicznego przedłużania i przeglądu restrykcji wobec Krymu, grupy sankcji „krymskich”. Należy zaznaczyć, że polityczna decyzja o kształcie listy pozostaje w rękach ambasadorów, COEST prowadzi bardziej rozbudowane dyskusje na temat tego kogo usunąć, a kogo zostawić, choć nikt nie jest usuwany z powodów politycznych, tylko osoby zmarłe. Odnośnie pierwszych sankcji, czyli kontaktów z Rosją, to powinno się to odbywać przez COEST, ale jest to w praktyce rozproszone - trochę w COEST, trochę w PSC, trochę w COREPER.

COREPER, który opracował sankcje sektorowe de facto, już się nimi nie zajmuje z tego powodu, że one są przedłużane na szczeblu szefów państw. Aktualnie COREPER zajmuje się migracjami i kwestią Południa. PSC jest praktycznie wyłączone z całego procesu. W sytuacji o potrzebie decyzji o przedłużeniu sankcji, Przewodniczący Rady doprowadza do takiej sytuacji poprzez swoje nieformalne rozmowy przed posiedzeniami, że konsensus już jest w momencie, gdy liderzy przyjeżdżają na sesje 
Rady Europejskiej. Tak naprawdę na radach nie ma dyskusji na temat tego, co należy robić z sankcjami. Tematy rosyjskie są w Radzie rzadkie od dwóch lat, nie ma żadnych szerokich, kierunkowych dyskusji na temat przyszłości relacji Unii z Rosją. Czasami niektóre państwa zgłaszają pewne uwagi, ale generalnie się zgadzają. Dochodzi się do porozumienia „kuluarowo”, a później wydawana jest dyrektywa i wchodzi w życie kolejne przedłużenie. COEST dostaje mandat z Rady Europejskiej do przedłużenia, ale dyskusji na ten temat niema. Rozmówcy są zgodni, że stworzenie możliwości dyskusji byłoby dość problematyczne, ponieważ mogłyby się pojawić dość poważne i podważające stanowisko Unii argumenty, jak na przykład to, że Ukraina blokuje implementację porozumień mińskich, albo że Verkhovna Rada nie przyjmuje takich aktów prawnych, jakie powinna przyjąć. Takie głosy nie są otwarte, ale słychać je w nieformalnych rozmowach.

$\mathrm{Na}$ COEST aktualnie dyskutowane są kwestie o sytuacji praw człowieka, o możliwych formach wsparcia społeczeństwa obywatelskiego w Rosji, o możliwych działaniach na rzecz wsparcia obrońców praw człowieka i również na temat wojny informacyjnej. Wszelkie inne tematy są unikane, by nie podkopywać kruchego konsensusu politycznego, przedłużanego co pół roku. Jest pewna obawa, żeby nie dyskutować strategicznie o przyszłości stosunków Unii z Rosją, ponieważ może się okazać, że konsensusu nie ma, a on tak naprawdę jest.

\section{Skuteczność sankcji UE wobec Rosji}

Sankcje nie spowodowały zmiany ,zachowania” Rosji, choć takie było ich założenie. Co więcej, Rosja zastosowała swój kontratak, który w pewien sposób wpłynął negatywnie na sytuację niektórych przedsiębiorstw w Polsce, Niemczech itd., choć one były w stanie zmienić sobie kierunki handlu, zdobyć nowych partnerów. Kontrsankcje pasowały również pod rosyjską politykę żywnościową z 2010 roku, żeby uniezależnić od importu z krajów zachodnich i aby nie dyktowano Rosji warunków (Pospieszna, Stępień, Skrzypczyńska, 2018). W rezultacie przedsiębiorstwa rosyjskie też dają sobie jakoś radę. Pytani o skuteczność, prawie wszyscy rozmówcy byli zdania, że sankcje nie działają, ale trzeba je wprowadzać. Sankcje trwają i są przedłużone na kolejne pół roku. Konsensus się jeszcze utrzymuje co do twardego podejścia wobec Rosji, które Unia przyjęła w trakcie kryzysu ukraińskiego, ale jednocześnie wychodzą bardzo pragmatyczne tendencje, które są związane z klasycznym, bazowym nastawieniem pewnych państw do Rosji. W ciągu ostatniego półtora roku odbyło się sporo wizyt dwustronnych państw członkowskich w Rosji na różnych szczeblach, często bardzo wysokich szczeblach. Niemniej jednak UE zachowuje pryncypialne podejście.

Nie można w polityce międzynarodowej znieść tak łatwo sankcji, które raz zostały nałożone, ponieważ jest to bardzo wyraźny symbol dyplomatyczny i polityczny. Nikt się nie odważy znieść jednorazowym posunięciem sankcji nałożonych na Rosję, ponieważ, aby uzasadnić taki ruch musiałby być zaobserwowany jakiś wyjątkowo pozytywny ruch ze strony Rosji. Rosja od kilku lat coraz bardziej eskaluje napięcie, np. w Syrii, na Bliskim Wschodzie ogólnie. Nie ma okoliczności geopolitycznych, które uzasadniałyby tak radykalny ruch jak zniesienie sankcji. Dlatego normalizacja 
stosunków Unii z Rosją będzie możliwa dopiero po pełnej implementacji przez Rosję, ale i przez Ukrainę, jak niektórzy uważają, uzgodnień mińskich. Cała podstawa ideologiczno-dyplomatyczna jest zachowywana, ale z miesiąca na miesiąc zwiększa się dynamika kontaktów z Rosją.

$\mathrm{Na}$ razie Unia nie reaguje na żadne kroki Rosji wspomniane powyżej. Istnieje jednak inna obawa, którą zasygnalizowali członkowie państw opowiadających się za sankcjami wobec Rosji, że będą próby, aby osłabić system sankcyjny w nieco inny sposób, np. poprzez wprowadzenie stopniowalności sankcji. Zasadą jest, póki co, że zmiana podejścia do Rosji jest uzależniona od pełnej, a nie częściowej implementacji postanowień mińskich. Gdyby Unia pozwoliła na podejście sankcyjne wobec Rosji tzw. „małych kroczków”, to Rosja zaczęłaby takie kroczki robić. Jak to określił jeden z rozmówców: ,„poprzez stopniowalność można doprowadzić do zniszczenia systemu, dlatego stopniowalność jest zła”.

Ponadto, zagrożeniem byłaby też zmiana stanowiska Francji i Niemiec, czyli znaczące zmiękczenie stanowiska wobec tych dwóch krajów: Rosji i Ukrainy. Istnieje ryzyko tzw. „zmęczenia Ukrainą”. Na razie dość skutecznie udaje się krajom członkowskim, przychylnym Ukrainie, podtrzymywać pozytywną atmosferę, wskazując na to, że mimo problemów są realizowane na Ukrainie reformy, może nie w sposób doskonały, ale jak na Ukrainę jest to dość progresywne. Zbliżają się wybory na Ukrainie i wszyscy mają obawy, że w długim okresie przedwyborczym te reformy ulegną jeszcze większemu spowolnieniu niż ma to miejsce obecnie, przez co kraje przychylne Ukrainie będą miały jeszcze mniej argumentów, by pokazać, że Ukraina to „success story”. Oprócz tzw. „zmęczenia Ukrainą” to co jeszcze mogłoby wpłynąć na zmianę pozycji Francji i Niemiec wobec sankcji nałożonych na Rosję, to gdyby Rosja zmieniła swoją politykę w innym, kluczowym regionie świata, np. w Syrii, która to zmiana z punktu widzenia władz Francji bądź Niemiec byłaby postrzegana jako korzystna.

\section{Podsumowanie}

Sankcje ekonomiczne są jednym z głównych narzędzi wspólnej polityki zagranicznej i bezpieczeństwa (CFSP) Unii Europejskiej. Jednak pomimo pojawienia się sankcji jako popularnego instrumentu w unijnej polityce zagranicznej, nadal niewiele wiadomo na temat procesu decyzyjnego podejmowanego przez tę organizację oraz skutków nakładanych sankcji.

Celem tego artykułu było wyjaśnienie procesu decyzyjnego UE dotyczącego sankcji, wykorzystując empiryczny przykład sankcji wobec Rosji. W szczególności celem było zrozumienie z czego wynika jednomyślność związana z nakładaniem i przedłużaniem sankcji wobec Rosji, biorąc pod uwagę odrębne postawy geopolityczne, motywacje ekonomiczne i czynniki ideologiczne. Badania sugerują, że czynniki geopolityczne oraz ekonomiczne mają bardzo duże znaczenie w tworzeniu dynamiki, jaka zachodziła w grupach doradczych Rady Europejskiej, niemniej jednak pomimo tych różnic w obliczu kryzysu ukraińskiego jednomyślność była i jest możliwa między państwami członkowskimi UE. Wytłumaczyć to można między innymi tym, że Francja i Niemcy odgrywają ważną rolę w podtrzymaniu tego konsensusu. 
Ponadto, strategiczne przeniesienie procesu decyzyjnego na najwyższe szczeble Unii Europejskiej, ogranicza możliwość dyskusji. Uruchomienie mechanizmu dyskusji w grupach roboczych takich jak COEST mogłoby spowodować, iż pojawiłyby się tradycyjne tendencje i podziały z okresu przedsankcyjnego oraz to, że konsensus jest kruchy. Ze strony Niemiec widać pewne sygnały na temat większego otwarcia wobec Rosji, zwłaszcza w sprawach gospodarczych, ale póki co to wszystko jeszcze nie łamie konsensusu. Jakakolwiek dyskusja doprowadzić mogłaby do zaostrzenia stanowiska Unii wobec Rosji i wzmocniłaby działania Rosji mające na celu podważenie konsensusu poprzez np. manipulowanie przy wyborach, tworzenie kontaktów gospodarczych z krajami członkowskimi.

\section{Bibliografia}

Allen S. H. (2005), The Determinants of Economic Sanctions Success and Failure, „International Interactions", nr 31 (2), ss. 117-138.

Art R. J., Cronin P. M. (2003), The United States and Coercive Diplomacy, The United States Institute for Peace, Washington.

Askari H. G., Forrer J., Teegen H., Yang J. (2003), Economic Sanctions: Explaining their Philosophy and Efficacy, Praeger, Westport, CT.

Cortright D., Lopez G. A. (2000). The Sanctions Decade: Assessing UN Strategies in the 1990s, Boulder, Lynne Rienner, Colorado.

Drury A. C., Peterson T. (2011), Sanctioning Violence: The Effect of Third-Party Economic Coercion on Militarized Conflict, „Journal of Conflict Resolution”, nr 55 (4), ss. 580-605.

Elliott K. A., Uimonen P. P. (1993), The Effectiveness of Economic Sanctions with Application to the Case of Iraq, „Japan and the World Economy”, nr 5 (4), ss. 403-409.

Eriksson M. (2011), Targeting Peace: Understanding UN and EU Targeted Sanctions, Ashgate, Farnham.

Escribà-Folch A. (2012), Authoritarian Responses to Foreign Pressure: Spending, Repression, and Sanctions, „Comparative Political Studies”, nr 45 (6), ss. 683-713.

Escribà-Folch A., Wright J. (2010), Dealing with Tyranny: International Sanctions and the Survival of Authoritarian Rulers, „International Studies Quarterly”, nr 54 (2), ss. 335-359.

Galtung J. (1967), On the Effects of International Economic Sanctions: With Examples from the Case of Rhodesia, „World Politics”, nr 19 (3), ss. 378-416.

Giumelli F. (2011), Coercing, Constraining and Signalling: Explaining UN and EU Sanctions after the Cold War Francesco, ECPR Press, Colchester.

Hufbauer G. C., Schott J. J., Elliott K. A., Oegg B. (2007), Economic Sanctions Reconsidered, Peterson Institute for International Economics, Washington, DC.

Lindsay J. M. (1986), Trade Sanctions As Policy Instruments: A Re-Examination, „International Studies Quarterly", nr 30 (2), ss. 153-173.

Pape R. A. (1998), Why economic sanctions still do not work, „International Security”, nr 23 (1), ss. 66-77.

Peksen D. (2009), Better or Worse? The Effect of Economic Sanctions on Human Rights, „Journal of Peace Research", nr 46 (1), ss. 59-77.

Peksen D., Drury A. C. (2010), Coercive or Corrosive: The Negative Impact of Economic Sanctions on Democracy, „International Interactions”, nr 36 (3), ss. 240-264.

Portela C. (2012), European Union Sanctions and Foreign Policy: When and Why Do They Work?, Routledge, London. 
Pospieszna P., Weber P. (2017), Carrots or Sticks: The Choice and Impact of EU Democratic Sanctions and Aid, „V-Dem Working Paper”, https://www.v-dem.net/media/filer_public/d1/c6/ d1c6216d-2205-475a-95a5-b97399dccb66/users_working_paper_10.pdf.

Pospieszna P., Stępień B., Skrzypczyńska J. (2018), Russia’s Response to Western Sanctions: The Protectionist Strategy to Benefit Domestic Production and Consumption?, Prezentowany na konferencji International Trade and Finance Association (IT\&FA) Conference 2017, UEP Poznań.

Schneider G., Weber P. M. (2017), How Many Hands to Make Sanctions Work? Unilateral vs. Multilateral Economic Statecraft, Unpublished Working Paper.

Stępień B., Pospieszna P., Skrzypczyńka J. (2016), Challenges in evaluating impact of sanctions - political vs economic perspective, „Przegląd Politologiczny”, nr 4, ss. 155-168, DOI: 10.14746/ pp.2016.21.4.12, http://pressto.amu.edu.pl/index.php/pp/article/viewFile/7260/7277.

Tostensen A., Bull B. (2002), Are Smart sanctions Feasible?, „World Politics”, nr 54 (3), ss. 373-403.

\section{Streszczenie}

Celem przedstawionych badań jest analiza procesu decyzyjnego w UE w odniesieniu do nakładania i rozszerzania sankcji wobec Rosji oraz ocena przyczyny trwałości decyzji i porozumienia między państwami członkowskimi UE, pomimo odmiennego stanowiska. W szczególności artykuł analizuje proces decyzyjny, dynamikę oraz zmiany zachodzące w ramach grup roboczych Rady, takich jak COEST (Grupa Robocza ds. Europy Wschodniej i Azji Środkowej) dla Ukrainy, Białorusi oraz Rosji. Badania pokazują, że czynniki geopolityczne oraz ekonomiczne mają bardzo duże znaczenie w tworzeniu dynamiki, jaka zachodziła w grupach doradczych Rady Europejskiej, niemniej jednak pomimo tych różnic jednomyślność jest w dużej mierze wynikiem działań Francji i Niemiec.

Słowa kluczowe: sankcje Unii Europejskiej, sankcje ekonomiczne, polityka zagraniczna UE, Rosja, proces decyzyjny UE

\section{Sanctions of the European Union towards Russia: decision-making process, persistence, and the role of the Member States}

\section{Summary}

The aim of the presented research is to analyze the decision-making process in the EU with regard to imposing and extending sanctions against Russia and to assess the cause of the sustainability of decisions and agreements between EU Member States despite their different position towards sanctions. In particular, the article analyzes the decision-making process, dynamics and changes taking place within the Council's working groups, such as COEST (Working Group on Eastern Europe and Central Asia) for Ukraine, Belarus and Russia. Research shows that geopolitical and economic factors are very important in creating dynamics that takes place in advisory groups of the European Council; nevertheless, despite these differences, unanimity is observed that is largely the result of the actions of France and Germany.

Key words: sanctions of the European Union, economic sanctions, EU foreign policy, Russia, decision-making process of the European Union 
